\title{
Recent changes in breeding abundance and distribution of the Common Pochard (Aythya ferina) in its eastern range
}

\author{
Alexander Mischenko ${ }^{*}$, Anthony David Fox² ${ }^{*}$ D, Saulius Švažas ${ }^{3}$, Olga Sukhanova ${ }^{4}$, Alexandre Czajkowski ${ }^{5}$,
} Sergey Kharitonov ${ }^{1}$, Yuri Lokhman ${ }^{6}$, Oleg Ostrovsky ${ }^{7}$ and Daiva Vaitkuviene $\dot{e}^{3}$

\begin{abstract}
Background: The Common Pochard (Aythya ferina) (hereafter Pochard), a widespread and common freshwater diving duck in the Palearctic, was reclassified in 2015 from Least Concern to Vulnerable IUCN status based on rapid declines throughout its range. Analysis of its status, distribution and the potential causes for the decline in Europe has been undertaken, but there has never been a review of its status in the major part of its breeding range across Russia to the Pacific coast.
\end{abstract}

Methods: We reviewed the scientific literature and unpublished reports, and canvassed expert opinion throughout Russia to assess available knowledge about changes in the species distribution and abundance since the 1980s.

Results: While accepting available information may not be representative throughout the entire eastern range of the species, the review found marked declines in Pochard breeding abundance in the last two decades throughout European Russia. Pochard have also declined throughout Siberia. Declines throughout the steppe region seemed related to local drought severity in recent years, necessitating further research to confirm this climate link at larger spatial scales. Declines in the forest and forest-steppe regions appeared related to the major abandonment of fish farms in western Russia that had formerly provided habitat for breeding Pochard. However, hyper-eutrophication of shallow eutrophic lakes, cessation of grazing and haymaking in floodplain systems necessary to maintain suitable nesting habitat and disappearance of colonies of the Black-headed Gull (Chroicocephalus ridibundus) in a number of wetlands were also implicated. Increasing invasive alien predator species (e.g. American Mink Neovison vison and Raccoon Dog Nyctereutes procyonoides) and increasing spring hunting were also thought to contribute to declines. Reports of expansion in numbers and range only came from small numbers occurring in the Russian Far East, including on the border with China and the long-established isolated population on Kamchatka Peninsula.

Conclusions: Widespread declines throughout the eastern breeding range of the Pochard give continued cause for concern. Although we could address all the potential causal factors identified above by management interventions, we urgently need better information relating to key factors affecting site-specific Pochard breeding success and abundance, to be able to implement effective actions to restore the species to more favourable conservation status throughout its breeding range.

\footnotetext{
*Correspondence: almovs@mail.ru; tfo@bios.au.dk

${ }^{1}$ A.N. Severtsov Institute of Ecology and Evolution of the Russian Academy of Sciences, Leninskiy Street 33, Moscow 117071, Russia

2 Department of Bioscience, Aarhus University, Grenåvej 14, Kalø, 8410 Rønde, Denmark

Full list of author information is available at the end of the article
}

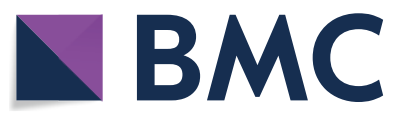

(c) The Author(s) 2020. This article is licensed under a Creative Commons Attribution 4.0 International License, which permits use, sharing, adaptation, distribution and reproduction in any medium or format, as long as you give appropriate credit to the original author(s) and the source, provide a link to the Creative Commons licence, and indicate if changes were made. The images or other third party material in this article are included in the article's Creative Commons licence, unless indicated otherwise in a credit line to the material. If material is not included in the article's Creative Commons licence and your intended use is not permitted by statutory regulation or exceeds the permitted use, you will need to obtain permission directly from the copyright holder. To view a copy of this licence, visit http://creativeco mmons.org/licenses/by/4.0/. The Creative Commons Public Domain Dedication waiver (http://creativecommons.org/publicdomain/ zero/1.0/) applies to the data made available in this article, unless otherwise stated in a credit line to the data. 
Keywords: Aythya ferina, Breeding, Common Pochard, Population declines, Population stressors

\section{Background}

Northern temperate zone wetlands are host to a guild of small to medium sized freshwater diving omnivorous duck species of the genus Aythya, which feed either within the water column or on benthic food resources. Some Aythya species of restricted distribution and specialism have shown recent declines in abundance and are subject to conservation actions (such as the Ferruginous Duck A. nyroca and Baer's Pochard A. baeri, Petkov et al. 2003; Wang et al. 2012). The majority are more widespread in North America or Eurasia and are important huntable species, for which reason their population status and trends have been subject to monitoring for many years. In North America, all but the Lesser Scaup (A. affinis) (Afton and Anderson 2001) have shown stable or slightly increasing abundance back to the mid1950s (U.S. Fish and Wildlife Service 2019). In Eurasia, both the Tufted Duck (A.fuligula) and Common Pochard (A. ferina) (hereafter Pochard) were widespread, common and expanding in range in Western Europe until the 1980s and 1990s (Wetlands International 2017). In the case of the Pochard, numbers have shown particularly dramatic declines since that time, especially in western Europe where the species has been reasonably well monitored, making this species a particular focus for conservation concerns (Fox et al. 2016).

The Pochard is a predominantly freshwater diving duck, common and widespread as a breeding species south of the tundra and northern taiga across the Palearctic from Far East Russia and the Daurian steppe lakes of eastern Mongolia in East Asia across to Iceland in the extreme west of Europe (Kear 2005). It winters west and especially south of its breeding range throughout Europe, North Africa, Mediterranean, Black and Caspian Seas, the Indian subcontinent, through to southern China, Korea and Japan (Kear 2005). Most recent estimates suggest a global population of between 1.23 and 1.33 million individuals (Wetlands International 2019), but showing substantial declines throughout the range compared to the last estimate of 1.95-2.45 million reported from the same source in Fox et al. (2016). After expansion in its western European range since the 1850s, serious reductions in range and abundance from the late twentieth century resulted in the upgrading of the Pochard from IUCN category Least Concern to Vulnerable on the basis of a $30-40 \%$ population decline over three generation spans (22.8 years; BirdLife International 2015). Winter counts in western Europe showed declines of 50\% from the late 1980s to 2012 to number just 150,000 individuals and similar declines in the Mediterranean/Black Sea region to 600,000 there (Nagy et al. 2014). Pochard feed on plant and animal food obtained by diving, especially the oospores of Charaphytes and the fruits of submerged macrophytes such as Potamogeton and Polygonum spp. (Olney 1968; Cramp and Simmons 1977). The dependence on relatively meso- and eutrophic waters with a clear water column in which such plants are most abundant and accessible makes the species susceptible to changes in freshwater trophic states and water transparency because of eutrophication (e.g. Fox et al. 2019). In a comprehensive review of the factors affecting recent declines in the population in Europe, Fox et al. (2016) concluded, based on expert opinion, that intensification and abandonment of freshwater fish farming and hypereutrophication of shallow eutrophic lakes were likely the major causes of these declines, although the contribution from other factors could not be ruled out.

The Pochard is a relatively new breeding species in the temperate forest subzone of Eastern Europe, established as a breeding species in the central part of European Russia and the Baltic States by the end of the nineteenth century (Polyakov 1910; Tischler 1941; Kalela 1949). Pochard arrived as a breeding species to Belarus, northern Ukraine and northwest European Russia during the first 2 decades of the twentieth century (Merikallio 1929; Fedyushin and Dolbik 1967; Malchevsky and Pukinsky 1983; Lysenko 1991). Its distribution in the temperate subzone is fragmentary, breeding in shallow eutrophic water bodies with rich aquatic vegetation, mainly in open landscapes (Viksne et al. 2010). It was a rare breeder throughout much of the temperate subzone in the early twentieth century (Ivanauskas 1959; Ptushenko and Inozemtsev 1968; Vyazovich 1973), but numbers rapidly increased in the 1960-1980s, which coincided with a period of construction of major fishpond systems, as well as the creation of reservoirs and other artificial wetlands suitable for nesting Pochard in the region.

Throughout the region, Pochard breed on islets of floating plants or reed swamps in lakes and artificial water bodies, on open islets or on tussocks in wet meadows and sedge swamps, including near small lakes and oxbows in floodplains (Ptushenko and Inozemtsev 1968; Malchevsky and Pukinsky 1983; Mischenko 1985; Zubakin et al. 1998; Sotnikov 1999). Many breeding Pochard use artificial water bodies (e.g. fishponds, storage reservoirs, peat cuttings, sedimentation ponds etc.), e.g. $>50 \%$ in the Moscow Region were reported from fishponds in the 1980s (Mischenko and Sukhanova 
2006). The highest breeding temperate forest subzone densities were recorded on shallow eutrophic lakes (up to 30 pairs/100 ha), in floodplains of lakes/rivers (up to 20 pairs/100 ha) and on fishponds (up to 21 pairs/100 ha; Viksne et al. 2010). The largest reported aggregations of Pochard have been associated with colonies of Blackheaded Gull (Chroicocephalus ridibundus), Common Gull (Larus canus) and Black Tern (Chlidonias niger) (Mischenko 1985; Sotnikov 1999; Voronov et al. 2016) because of the protection against predator species that these provide (Viksne 1997; Väänänen 2000; Ostrovsky and Natykanets 2005; Khrabry 2016; Väänänen et al. 2016). However, in the steppe zone (extending to the Azov Sea) Pochard avoid gull colonies, particularly those of Caspian Gull (Larus cachinnans), which is a serious predator of Pochard nests (Zavjalov et al. 2005 and see later).

Europe constitutes less than one third of the breeding range of the species, so what is happening elsewhere in the range? Regular mid-winter counts in Japan, in the very far eastern wintering areas increased from the 1970s, peaked in the 1990s and have declined since that time, very much in parallel to trends in Europe and the Black Sea/Mediterranean regions (Biodiversity Centre of Japan 2019), but mid-winter monitoring elsewhere in Asia provides less clear trends (Mundkur et al. 2017). Pochard commonly breed in central and southern parts of European Russia, penetrating into the mid-taiga subzone of the boreal forest, reaching southern Karelia and Onezhskoye Lake and approximately $60^{\circ}$ north in the east of the European Russia (Stepanyan 2003). In the taiga forest zone, its distribution is fragmentary because most water bodies tend to be oligotrophic, whereas Pochard prefer to breed in shallow (typically 1-2.5 m) rich mesotrophic or eutrophic water bodies located mainly in open landscapes, typically with rich aquatic vegetation. Such wetlands are more common in the forest-steppe and especially steppe zones from European Russia throughout Siberia, reaching to Kamchatka and Khanka Lake in the extreme east (Syroechkovskiy 2011). One possible means of assessing the conservation status of the species in the major part of its breeding range to the east of Europe is therefore to assess changes in recent breeding distribution and abundance within the Russian Federation. For this reason, we here review the scientific literature and unpublished reports to assess available knowledge about changes in the species distribution and abundance since the 1980s.

\section{Methods}

We took a similar approach to that of Fox et al. (2016), contacting regional experts throughout European and Siberian Russia to the Far East. We attempted to compile information on local and regional Pochard status and trends from a literature search of published sources, as well as unpublished count databases and reports for as many regions as possible. Total counts of breeding Pochard are presented from sites subject to long-term investigations of the species in European Russia and Siberia (mainly from eutrophic lakes, fishponds and water reservoirs) based on either round counts (observers circling water bodies on foot or in a boat) or point counts (censused from fixed points on the shore, after Koskimies and Väisänen 1991). Standard line transect methods determining breeding densities of ducks (counting ducks in selected routes of up to $5 \mathrm{~km}$, within $400 \mathrm{~m}$ wide zone) were applied at certain sites (mainly river sections, in floodplains and coastal lagoons). Nesting pair abundance was estimated by counting females with or without males during the local breeding period. Standard total counts and line transect methods based on aerial or boat surveys were used to estimate post-breeding Pochard abundance (particularly in coastal wetlands of the Azov and Caspian Sea) using the methods of Komdeur and Bertelsen (1992). The objective was to develop a spatially explicit profile of past and current breeding status (over whatever timespan might be available), to estimate the trend in abundance of breeding pairs over the last two decades for short-term trends and since the 1980s where possible for longer-term trends. We canvassed opinion about the likely factors to have differentially affected female survival and reproductive output (e.g. predation pressure), as well as in habitat quality change affecting food availability and quality, nesting cover and general attractiveness to breeding Pochard. While we fully appreciate that much of the information so derived is fragmentary and with many gaps, we face the reality that there exist few other sources of data upon which to base our assessment of the population status of this species in these parts of its breeding range.

\section{Results \\ European Russia}

Data are available on changes in breeding Pochard abundance from 22 survey sites located in 14 administrative regions in European Russia as shown in Fig. 1, discussed below in the context of the 3 major biomes occupied by the species.

\section{Forest zone}

The Pochard was only an occasional breeder in the Leningrad Region until colonisation in the first 2 decades of the twentieth century (Merikallio 1929; Malchevsky and Pukinsky 1983). By the late 1960s, Pochard were commonly breeding on Ladozhskoye Lake and in South Karelia (Neifeldt 1970), with the greatest densities on the 


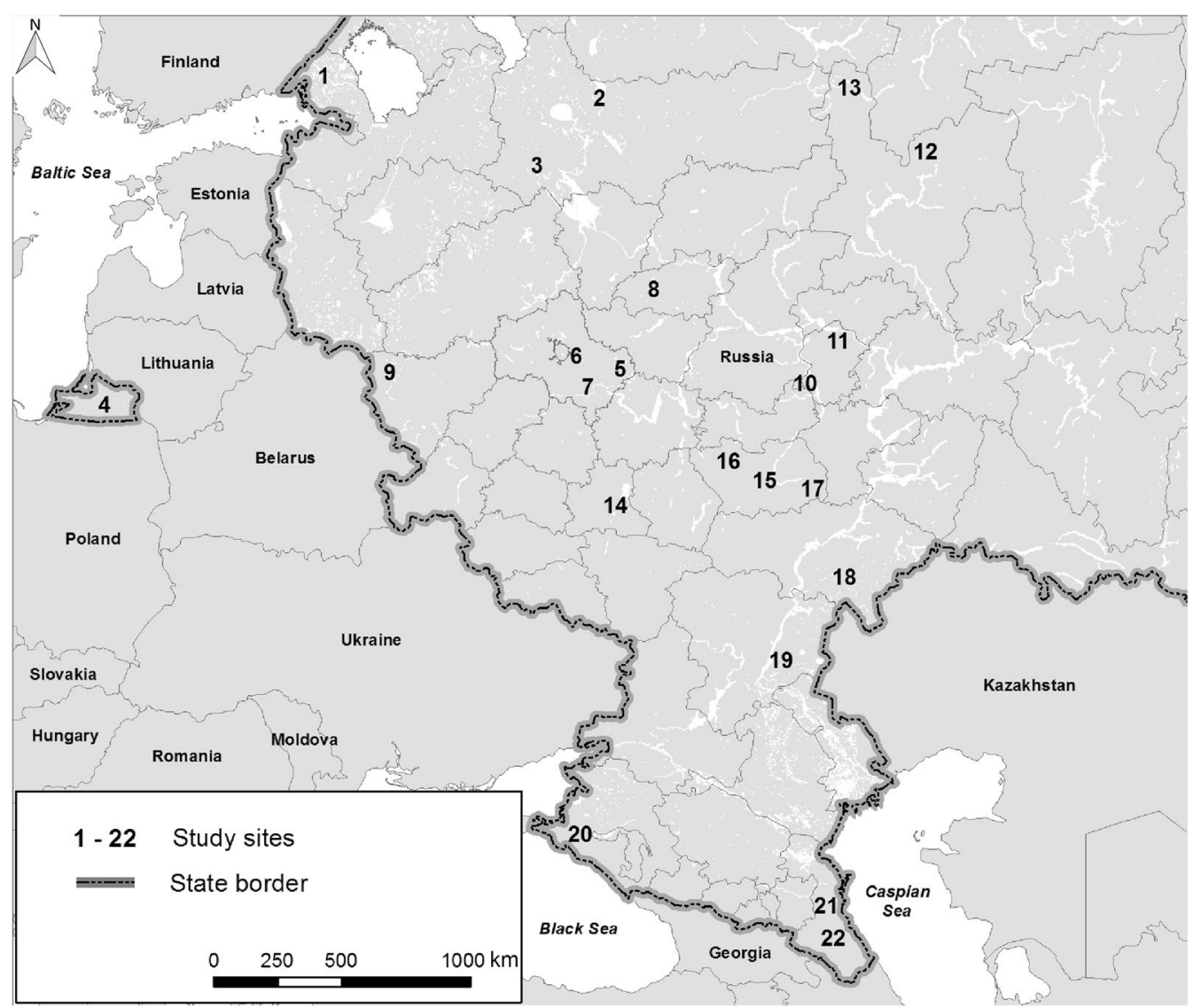

Fig. 1 Location of the sites/wetlands with regular data on breeding Common Pochard habitat and abundance in European Russia. Numbers on the map correspond to numbers used to identify sites/wetlands in text

Rakovye Lakes (site 1, Fig. 1) in Karelia, the Narvskoye reservoir and where the Svir River empties into Ladozhskoye Lake (Malchevsky and Pukinsky 1983). Eastwards from the river Volkhov, Pochard were very rare even in the 1990s due to lack of suitable water bodies. By 2011-2015, the annual post-breeding Pochard population in the Leningrad Region was estimated at 3000-4000 (adults and juveniles combined, State Hunting Inventory of the Leningrad Region in litt). At Rakovye Lakes, numbers of breeding pairs increased from 400 pairs in 1925 (Merikallio 1929) to c. 500 pairs in the early 1970s (Moskalev 1977) but fell back to c. 30 pairs in 1999 and 2000 (Iovchenko 2012; Khrabry 2016).

In the Vologda Region, only the large shallow Lake Vozhe (site 2, Fig. 1) held more than 100 breeding pairs (2010-2013), although trends are unknown (Miklin et al. 2013); elsewhere in this region, there has been a fivefold decline in breeding Pochard numbers on small shallow lakes and former gravel pits (D. Shitikov pers. comm., site 3, Fig. 1).
Pochard bred commonly in the Kaliningrad Region (former Eastern Prussia) in the 1930s, especially in the Neman Delta, Curonian and Vistula Lagoons (Tischler 1941), but have declined significantly in the last thirty years (Grishanov and Švažas 2013). Breeding numbers in the southern part of the Curonian Lagoon (site 4, Fig. 1) declined from more than 100 pairs in 1940 (Tischler 1941) to irregularly single breeding pairs in the last decade, where staging migratory numbers also declined from 3000 in 2000 to 1000 in 2010 (Grishanov and Švažas 2013).

Pochard first bred in the Moscow Region in 1890 and spread to nest on several lakes in the early 1900s (Polyakov 1910), although remaining rare until the late 1950s (Ptushenko and Inozemtsev 1968). Shallow lakes on peat exploitation sites formerly supported up to 17 broods $\mathrm{km}^{2}$ (site 5, Fig. 1; Mischenko 1985), but by 2018, these areas were completely over grown by Wild Rice (Zizania aquatica) and Pochard were absent. During the 1950 s and 1960s, $185 \mathrm{~km}^{2}$ of reservoirs, $67 \mathrm{~km}^{2}$ of fishponds and $243 \mathrm{~km}^{2}$ of peat extraction sites were created in this 
region. Such novel, artificial wetlands (with many small islands, shallow water and abundant colonies of gulls/ terns) provided ideal conditions for breeding Pochard. Moscow Region fishponds held up to 200 breeding pairs in early 1980s, many supporting high breeding densities (up to 24-25 pairs per 100 ha within gull colonies, Mischenko 1985; Sukhanova 1996), although numbers have fallen since. Currently, only small numbers breed irregularly on certain fishponds, as for example at Biserovo fishponds (site 6, Fig. 1) where numbers fell from 27 pairs during 1981-1983 to only 3 in 2018 (Fig. 2). Loss and/ or deterioration of the open water habitats in the Moscow Region since 2000 has caused the almost total disappearance of Pochard as a breeding species (Mischenko and Sukhanova 2006). The Vinogradovo Floodplain (site 7, Fig. 1) is one of the few natural floodplain wetlands in the Moscow Region, extending to some $50 \mathrm{~km}^{2}$. This area supported up to 200 breeding females in the early 1980s (Zubakin et al. 1998), but numbers declined markedly during the 1990s, with no breeding birds recorded in 1999-2004 (Mischenko and Sukhanova 2016a). Since then, numbers have varied widely from just two females in 2005 to a maximum of 57 in 2013, but numbered less than five in 2017 and 2018. In contrast, numbers of breeding Pochard using abandoned flooded peat cuttings from the middle of the last century in Ivanovo Region (site 8, Fig. 1) have showed fewer signs of recent decline since the early 2000s (Chudnenko 2017). Breeding Pochard also declined from c. 20 pairs in the early $2000 \mathrm{~s}$ to none in 2017 Kasplyanskiy Fishponds (c. 300 ha, site 9, Fig. 1) in Smolensk Region.

Breeding Pochard were never abundant in the Chuvashya Republic and remain fragmentary in their distribution, numbering c. 200-300 breeding females

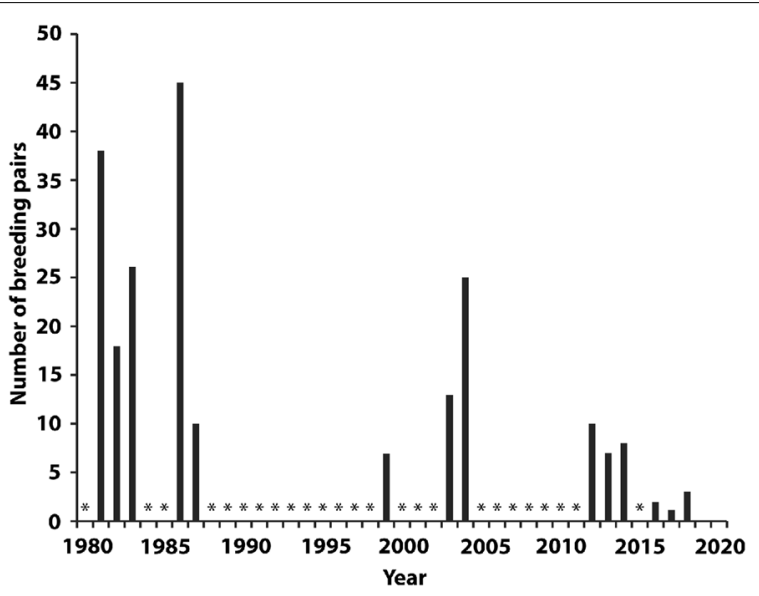

Fig. 2 Annual numbers of Common Pochard broods observed in Biserovo Fishponds, Moscow Region during 1981-2018, asterisks indicate years lacking data
(Voronov et al. 2016), some on ponds in the cities of Alatyr and Novocheboksarsk (sites 10 and 11, Fig. 1; Glushenkov et al. 2007; Voronov et al. 2016). Numbers in Alatyr have fluctuated without trend from the late 1990s to the present, whereas Novocheboksarsk numbers fell from 15-28 pairs during 2001-2007 to 1-3 pairs during 2009-2011 following the loss of large gull colonies (Voronov et al. 2016). Only in the Kirov Region have slight increases in numbers of breeding Pochard been recently registered in Nagorskiy (site 12, Fig. 1) and Podosinovskiy Districts (site 13, Fig. 1; V. Ryabov, pers. comm.).

\section{Forest-steppe zone}

Pochard have always been rare, sporadic and widely distributed in the forest-steppe zone until the mid-twentieth century. Local breeding was confined to a few large floodplains with networks of shallow-water oxbow lakes and well-developed aquatic vegetation, mainly in the Don floodplain below Voronezh. However, the construction of reservoirs, fishponds, sedimentation ponds, cooling ponds for power stations and other artificial wetlands created new habitats for nesting Pochard, resulting in marked increase in numbers in the late twentieth century. In fishponds and certain reservoirs, the development of abundant aquatic vegetation has been associated with local increases in abundance of Pochard, which has become a common breeding species. Locally its abundance has approached that of the Mallard Anas platyrhynchos, although always patchy in its breeding distribution (Numerov 1996; Klimov et al. 2004). However, since 2000, the species is reportedly in decline, especially at important sites for their concentrations of breeding Pochard. 20-40 Pochard broods per 100 ha were recorded at the Gryazinsky Fishponds (site 14, Fig. 1) during 2000-2010, with several hundred individuals counted post-breeding (Sarychev and Batishchev 2012), but this has fallen to $5-10$ broods per 100 ha since then.

Pochard did not breed in the Penza Region before the first record in 1978 (15 broods at Bobrovoye Lake), after the establishment there of a Black-headed Gull colony (see Frolov 2017). At Ust'-Uzinskiy fishponds (site 15, Fig. 1), Black-headed Gulls first nested in 1981 and Pochard breeding ( 5 broods) followed in 1982, increasing to 30 pairs counted in 1986. In 1990, the gull colony shifted to urban ponds in Penza city (site 16, Fig. 1) and Pochard followed them there (where up to 10 pairs have occurred since under the protection of gulls and Black Terns). Pochard abandoned the Ust'-Uzinskiy fishponds after 1989 in the absence of the gulls (Frolov 2017). The current breeding Pochard population in the region is estimated at about $250-500$ breeding pairs, but continues 
to decline, especially at key sites, such as the artificial lake at Selitbenskoye (site 17, Fig. 1; Frolov 2017).

\section{Steppe zone}

The steppe zone has always represented the core Pochard breeding zone in European Russia. Interestingly in this biome, especially south in the core steppe zone (extending to the Azov Sea), Pochard avoid gull colonies, particularly those of Caspian Gulls which predate eggs and ducklings (Zavjalov et al. 2005).

Breeding Pochard were common and widespread in the Saratov Region during the 1990s, especially on islands in the large Volga River reservoirs, large ponds and smaller reservoirs with abundant emergent and submerged vegetation (Zavjalov et al. 2005). In more traditional Pochard breeding habitats provided by steppe ponds, for instance in the Pugachevskiy district, numbers settling to breed always varied with local hydrological conditions, varying between 2.4 birds per $1 \mathrm{~km}$ of shoreline in 1992 (a dry year) and 5.2 birds in 1990 (a year with higher water levels, Zavjalov et al. 1997). Nevertheless, in many areas, breeding Pochard densities in steppe ponds have declined markedly in the last 10-15 years. For instance, few remain in the Eruslan River valley, which formerly held densities of 32.7 birds $\mathrm{km}^{2}$ in 1998-2002 (Sarantseva 2003) while numbers in an area of $443 \mathrm{~km}^{2}$ in the Saratovsky Nature Reserve in the Saratov Region (site 18, Fig. 1) have declined to just 15-20 pairs (A. Belyachenko, pers. com.). Although summering Pochard on the lakes of the Sarpinskaya Lowland in the Volgograd Region (site 19, Fig. 1) have remained at around 2200 birds during 2000-2018, most are moult migrant males from elsewhere in the region, so are unlikely to reflect local breeding abundance (Bukreev and Chernobay 2011; Mischenko and Sukhanova unpubl. data).

Nesting Pochard associated with heronries in shallow lagoons along Azov Sea coasts have declined dramatically since 2000 . Up to 700 birds were regularly counted post-breeding in the Priazovsky Nature Reserve in the Krasnodarskiy Region (site 20, Fig. 1) in the 1980s and 1990s, compared to few in 2011 and 2012 (Tilba and Mnatsekanov 2014). As elsewhere, post-breeding moulting numbers of Pochard have remained numerous over the same period, albeit showing major year-to-year abundance. Regular counts in July/August of aggregations along Azov Sea coasts have detected up to 36,500 individuals, but local annual abundance varies enormously, likely dependent on local and regional hydrological and climatic conditions throughout adjacent areas in Ukraine and Russia. In the Dagestan Republic, the Caspian Sea coastal lagoons of Sulak and Turali (sites 21 and 22, Fig. 1), annual Pochard breeding numbers have declined since the peak in 1999 (Fig. 3, Vilkov in press).

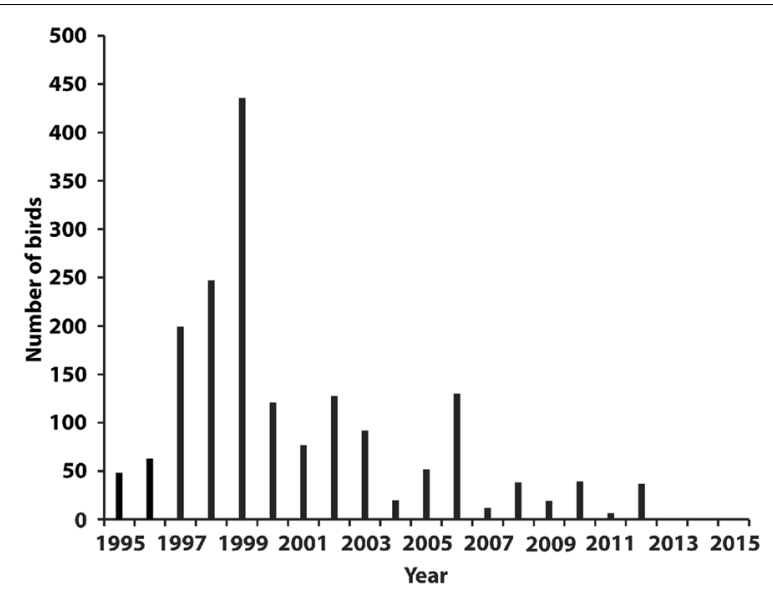

Fig. 3 Annual estimated breeding numbers of Common Pochard at Sulak and Turali lagoons combined, Caspian Sea, Dagestan Republic of Russia during 1995-2015 (Vilkov in press)

In summary, declines in breeding Pochard abundance in the last 20 years have been reported from five administrative regions in the steppe and steppe-forest zones of European Russia, compared to stable trends in only one region (Fig. 4).

The total breeding population in European Russia was estimated at about 90,000-120,000 pairs in 2017 (Mischenko 2017), compared to 95,000-265,000 pairs in 2004 (Mischenko 2004).

\section{Siberia}

Pochard breed in a continuous belt across Eurasia, throughout the steppe and southern forest zones of Siberia, reaching Yakutia in the east and north and the taiga to the north (Ryabitsev 2014). In West and Central Siberia, Pochard breed mainly in wetlands in the foreststeppe and steppe, especially in more open areas, becoming rarer and more patchily distributed in the taiga biome (Ryabitsev 2014). Post-breeding Pochard abundance in the 1990s was estimated at 700,000 individuals (Krivenko and Vinogradov 2008), but marked declines have been reported at monitored sites since that time. Here, we summarise the available data on changes in Pochard abundance from seven areas of Siberia (Fig. 5).

In the Tobol and Ishim forest-steppe area (site 1, Fig. 5) in southern Tyumen Region, West Siberia, the Pochard was a very abundant breeding species in the 1970s, with 83,500 breeding pairs estimated in 1970 . By the late 1970s, numbers were already declining, with 36,500 pairs estimated in 1977 and 12,800 in 1985 (Azarov 1991), while a further three-fold decline in numbers of breeding pairs was reported during 2000-2015 (Tarasov 2015).

On the lakes of the Kulunda steppe (West Siberia, site 2, Fig. 5) Pochard remains the most abundant breeding 


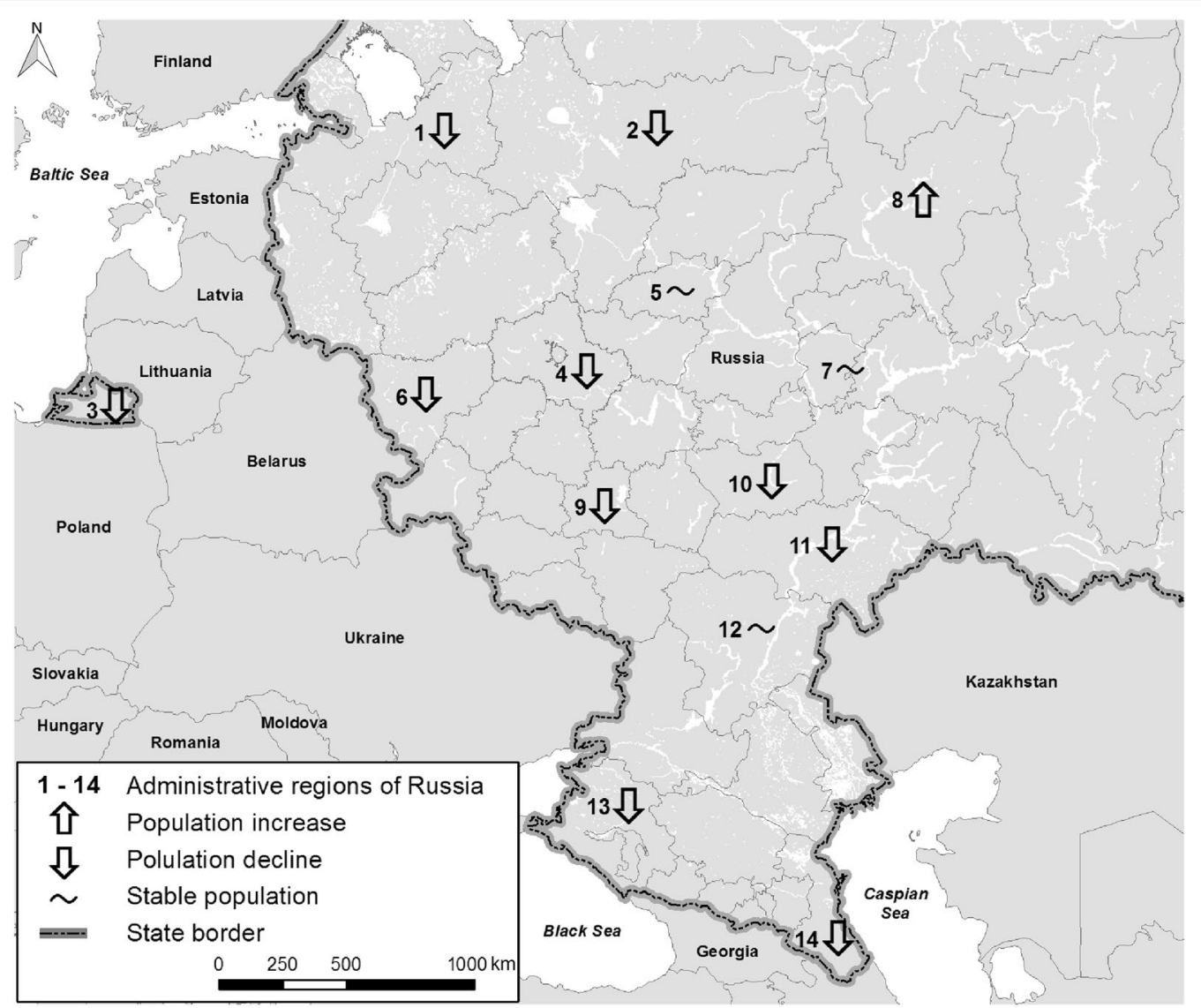

Fig. 4 Trends in numbers of the Common Pochard in 14 administrative regions of European Russia. Numbers refer to administrative regions identified as follows: 1 - Leningrad; 2-Vologda; 3-Kaliningrad; 4-Moscow; 5-Ivanovo; 6-Smolensk; 7—Chuvashia Republic; 8-Kirov; 9Lipetsk; 10-Penza; 11—Saratov; 12-Volgograd; 13—Krasnodar Territory; 14—Dagestan Republic

duck species although showing major fluctuations in numbers linked to summer drought conditions. However, the trend in overall abundance has been downwards, with May/June densities at monitored sites falling from a mean of $41.5 \pm 5.0 \mathrm{SE}$ birds $\mathrm{km}^{2}$ in the $1970 \mathrm{~s}$ to $5.6 \pm 1.3$ in the 1990s and $13.0 \pm 0.6$ in the 2000s (Mikhantyev and Selivanova 2016).

The southern steppes and forest-steppes of Western Siberia experienced severe droughts during 1975-1985, causing the lowest ever recorded water levels in steppe lakes during the mid-1980s and marked declines in breeding Pochard abundance during that period (Tarasov 2015; Mikhantyev and Selivanova 2016). Following a period of increased precipitation, water levels in lakes of the region increased from the 1990s until the mid-2000s, during which period breeding Pochard increased on the Kulunda steppe lakes. Following another very dry period in the hydrological cycle starting in 2005, Pochard have again shown a three-fold decline in breeding Pochard numbers in the Tobol and Ishim forest-steppe areas (Tarasov 2015).
Numbers of Pochard counted in early summer in the Krasnoyarsk Region forest-steppe zone of Central Siberia (site 3, Fig. 5) declined from a maximum of 91,000 and an annual mean of c. 43,000 in the 1980 s to about c. 14,500 individuals in 2003 (Zhukov 2006).

Pochard abundance monitored at three sites at Lake Baikal during the 1980s and 2000s showed declines in the proportion of Pochard of total duck numbers in the Selenga river delta in Buryatia Republic (site 4, Fig. 5) from the 1980s to 2009 (Fefelov et al. 1995, Fefelov in litt.). Pochard broods counted on Irkutsk urban wetlands (site 5, Fig. 5) fell from 40-70 broods annually in the late 1980s (Melnilkov et al. 2003) to just 10 in 2007 (Fefelov et al. 2009). However, an increase in numbers and breeding range was reported over the same period in the southern part of Irkutsk Region (site 6, Fig. 5, Fefelov et al. 2009).

In the late twentieth century, Pochard bred in the upper and middle Vilyui River basin, Yakutia Republic, well to the north of the continuous range of the species (Andreev 1987; site 7, Fig. 5). However, the species 


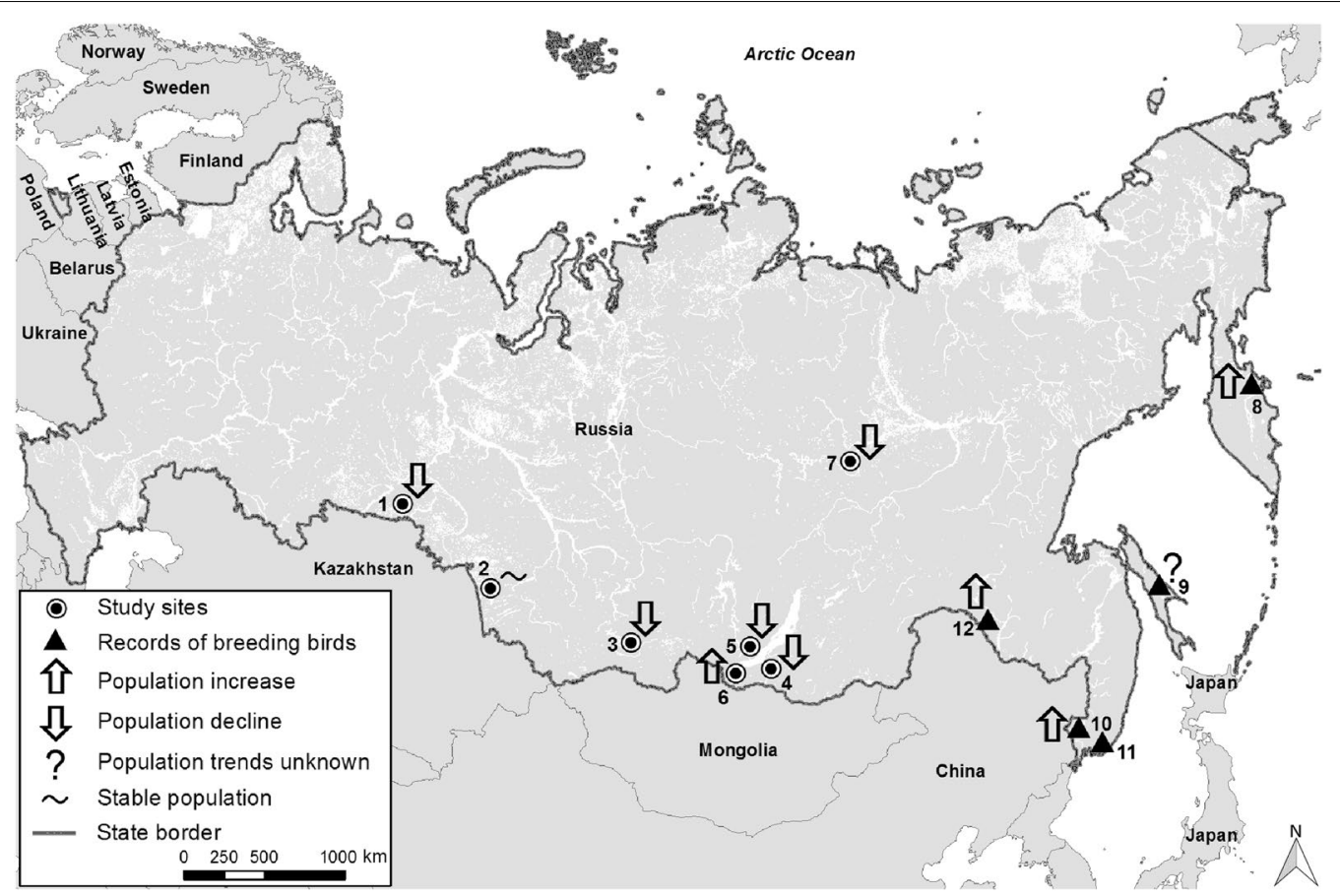

Fig. 5 Study sites and populations trends of the Common Pochard in Siberia and Russian Far East. Circles indicate case study sites and adjacent symbols identify the nature of the change in abundance at each over the last 2 decades. Triangles indicate confirmed breeding sites of the Common Pochard in Russian Far East. Numbers on the map correspond to numbers used to identify sites in text

had disappeared from the upper catchment in the 1990s and 2000s (Degtyarev 2007) and had become rare in the mid-Vilyui area, mostly confined to islands with colonies of Black-headed and Little Gull (Hydrocoloeus minutus) (Degtyarev 2004, 2007).

\section{Russian Far East}

In the Russian Far East, the only known, isolated breeding site for Pochard throughout the $18^{\text {th }}$ to twentieth centuries has been on Kamchatka Peninsula (site 8, Fig. 5). Georg Steller recorded Pochard there in June 1774 while adult and juvenile females were shot in the same area in 1930 (Lobkov 1986). Several individuals were recorded in this site in 1976 (Gerasimov and Gerasimov 2008). Some 500-1000 breeding and non-breeding Pochard were estimated to summer in Kamchatka in the 2010s, where the local breeding population is reported to be increasing (Gerasimov and Gerasimov 2014), although still confined to the Kamchatka River and adjacent lakes (Lobkov et al. in press).

On Sakhalin Island, breeding Pochard have been recorded on Nevskoye Lake on the Okhotsk Sea coast (site 9, Fig. 5). Pochard first bred there in the 1940s (Takahashi 1942) with a second record from the mid1980s (Voronov et al. 1983) and have bred there irregularly in very small numbers since.
Along the continental coast of Russian Far East, the Pochard was a rare vagrant species in the 1930s and remained so from the late $1940 \mathrm{~s}$ to the early $1950 \mathrm{~s}$ (Shulpin 1936; Vorobiev 1954, 1968). In the early 1960s, the Pochard began to become common on migration in the south-west close to the border with China and numbers migrating reported in this region have increased in the last two decades (Elsukov 2005, 2013). Rare summer records in the 1960s and 1970s were reported from the Lake Khanka lowlands (Polivanova 1971; Glushchenko et al. 2006) and after returning in June 2003, three broods were observed there in June 2004 (Glushchenko et al. 2005). Since 2005, the Pochard has been a regular breeding species in the Lake Khanka lowlands, near Dalnerechensk (site 10, Fig. 5) and numbers are increasing (Glushchenko et al. 2016), now spreading to breeding areas further south near Nakhodka (site 11, Fig. 5).

Vagrant Pochard were first reported along the Amur River in the late 1980s and although still rare, in increasing numbers have been reported since 2006 (Antonov and Parilov 2009), culminating in possible breeding during 2005-2017 on a small reservoir near Lazorevka (V. Dugintsov, pers. comm., site 12, Fig. 5). 


\section{Discussion}

\section{Potential explanations for declines in European Russia}

Summarising the overall trends in breeding abundance of Pochard in 14 administrative regions of European Russia, there were marked declines in the last two decades in 10 (Fig. 4). A slight increase was reported from only one region, while populations remained probably stable in three regions, mostly in eastern European Russia.

The core breeding population of the Pochard in European Russia are undoubtedly concentrated on wetlands in the steppe region. Such wetlands tend to be highly productive biologically, but being in semi-arid environments are highly susceptible to frequent hydrological fluctuation. A common feature of the Russian and Ukrainian ornithological literature is that the peak Pochard breeding densities were reported throughout the nineteenth and twentieth centuries, a period when many wetlands in this arid zone were relatively well recharged with rain and groundwater annually (Isakov and Ptushenko 1952; Lysenko 1991; Klimov et al. 2004; Krivenko and Vinogradov 2008). This has certainly not been the case in the same regions during the last two decades. For instance, the lake ecosystems of the Sarpinskaya lowlands in the Kalmykia Republic are very typical of very many similar systems throughout the steppe zone, important for their breeding and post-breeding moulting aggregations of Pochard (Ryazanova and Kravchuk 2017). The area of open water in one of these lakes, Sarpa Lake, progressively reduced through lack of recharge from $28 \mathrm{~km}^{2}$ in April 2005 to $8.5 \mathrm{~km}^{2}$ in April 2016, with corresponding reductions in September water area from 14.6 to $3.2 \mathrm{~km}^{2}$ over the same series of years (Ryazanova and Kravchuk 2017). A nearby lake (Barmantsak) formerly $5.1 \mathrm{~km}^{2}$ in extent in September 2005, was completely dried out in September from 2008 onwards (Ryazanova and Kravchuk 2017).

It seems likely that impacts of climate warming resulting in reduced precipitation and increased aridity in steppe zone of Ukraine have also caused the loss of suitable breeding habitats in many key sites for Pochard (Viksne et al. 2010). Large-scale drainage schemes and overgrowing of open islands of lakes and lagoons with shrubs and dense reed stands were also important factors causing the decline of Pochard population in steppe zone, particularly in coastal wetlands of the Black Sea (Serebryakov et al. 2003). Numbers fell, for example, in the Molochnaya River estuary from c. 100 pairs in 1988 to none in 2012 (Chernichko and Kostyushin 2015).

While such hydrological changes are having a dramatic effect on the extent and quality of breeding habitat in the heart of their traditional breeding range, Pochard also seem to be suffering in areas of European Russia where they have colonized artificial wetlands during the period of their expansion in range and abundance that continued up until the mid-1990s. Artificial wetlands, particularly fishponds managed for aquaculture, have become key breeding sites of Pochard in European Russia. Although the net production from Russian aquaculture increased from 105,500 tons in 2007 to 174,000 tons in 2016 (Kalinina and Zelenskaya 2018), the area of maintained fish farms declined rapidly during 1990-1997 and has continued to fall ever since due to shortage of cheap fish feed supplies and changing consumer preferences (FAO/EBRD 2008). Under the prevailing economic conditions, more than $70 \%$ of all existing fish farms in European Russia have ceased their activities during the last two decades. Abandonment leads to loss of water area, so many abandoned fishponds have rapidly overgrown with shrubs, bushes and tall grassy vegetation.

Even where aquaculture continues, the significant decrease in the availability of traditional fish fodder results in reductions in food resources available for breeding Pochard in much the same way as reported elsewhere in Eastern Europe (Fox et al. 2016). In Belarus, the total fish production in fish farms declined rapidly from c. 18,000 tons in 1990 to only 4300 tons in 2014 due to economic recession and increased costs of fish food. Currently fish farms use grain waste instead of compound food for fish feeding on most ponds and filling of many ponds with water starts about 1 month later than in previous years. While adult Pochard may be able to feed on this type of food in April and early May, waste grain is completely unsuitable as food for broods. Earlier, the diet of breeding Pochard on fishponds mainly consisted of the compound fish food (Švažas and Kozulin 2002), so recent changes in management of fishponds are likely to have contributed to the declines from 4100 Pochard pairs on fishponds in 1995 to 1800 pairs in 2001 and 800 in 2019 (Kozulin and Ostrovsky, unpublished data). Only 50\% of Pochard females participated in breeding in monitored fishponds in 2018-2019, and the rest stayed in mixed flocks with males throughout the breeding season. Successful broods were recorded only in 50\% of monitored nests on fishponds in 2018-2019. Breeding season initiation in these years started a month later compared to the breeding dates in the 1990s with the result that duckling hatched after the peak in aquatic insect biomass emergence, contributing to low breeding success of Pochard in Belarus fishponds (Kozulin and Ostrovsky, unpublished data). In contrast, in neighbouring Lithuania, breeding Pochard numbers on fishponds are stable or slightly increasing since 2000, due to ecological management of most fish farms. Good quality grain is used at most fish farms providing abundant food resources for breeding Pochard, supplemented by provision of artificial nest sites and reduced human disturbance. These 
factors likely contributed to the observed $75 \%$ production of broods from monitored ponds, where more than $95 \%$ of all females participated in breeding during 2016-2019 (Švažas, unpublished data). It is likely that changes in fishpond management and the loss of many fishpond complexes in European Russia may also have contributed to changes in the availability and quality of potential artificial Pochard breeding habitat in recent years, but these experiences suggest that such degradation in habitat could be reversed with appropriate changes to fishery management.

We also consider that, based on the assessment of experts consulted, the loss of large Black-headed Gull colonies in many European Russia wetlands in the 1990-2000s caused by the loss of food availability in open landfills and termination of fish farm activities has also had serious adverse consequences for breeding Pochard (Viksne et al. 2010; Mischenko and Sukhanova 2006, 2016a).

Away from steppe and fish-farming areas, shallow eutrophic lakes and river floodplain oxbow lakes are among the most important natural habitats for Pochard within the forest zone of European Russia. Recent climate change has reduced winter snowfall and the intensity of spring floods during the last two decades (Mischenko and Sukhanova 2016b), causing rapid succession and resulting in the overgrowth of open floodplain meadows by shrubs and bushes. These processes have been exacerbated by abandonment of traditional grazing and hay making due to recent changes in agricultural practices. Such scrubbing over of former meadows in the Vinogradovo Floodplain (Moscow Region) has lost $75 \%$ of formerly important breeding Pochard habitats and has lost much of their former importance for this species since the 2000s (Mischenko and Sukhanova 2016a). This mirrors similar declines in Lithuanian coastal floodplains (where maximum Pochard breeding densities declined from 20 pairs/100 ha in the 1990 s to 4 pairs/100 ha in 2010, Grishanov and Švažas 2013), but where reinstatement of appropriate grazing regimes could restore Pochard breeding habitat.

Some of the losses of breeding Pochard throughout Russia are also likely the result of hyper-eutrophication associated with shallow eutrophic lakes favoured by breeding Pochard. This is the case at Lake Osveyskoe in western Belarus, where the breeding population of Pochard declined from 550 breeding pairs in 1981 to up to 20 pairs in 2005-2018. This was thought due to the complex interaction of different responses to increased nutrient loads, affecting the whole lake ecosystem, including enhanced growth of emergent macrophytes, degradation of open shallow habitats, the loss of benthos biomass (primarily chironomids), major changes in fish communities and degradation of their spawning grounds (Ostrovsky and Natykanets 2009). At Lake Zuvintas, a similar shallow eutrophic lake in Lithuania, breeding densities of Pochard declined from 30 pairs/100 ha in the 1980s (Švažas et al. 1999) to 0.5 pairs/100 ha in 2018 (Švažas, unpublished data). However, even these changes need not be irreversible. Recent successful restoration schemes at hyper-eutrophicated shallow lakes formerly important for breeding Pochard have been implemented in Denmark (Fox et al. 2019) which could equally be implemented to enhancement conditions for locally breeding Pochard in similar habitats across the eastern extent of their range.

The impacts of increased predation by invasive species of mammals (particularly American Mink and Raccoon Dog) on Pochard have been described (Viksne et al. 2010) and are a feature of all areas where their distributions continue to overlap, but their true impacts are difficult to assess. In addition, recent expansion in the breeding ranges of the Caspian Gull and Herring Gull (Larus argentatus) has introduced an additional threat to the regional population of nesting Pochard where these gulls were previously absent (Frolov 2017; Mischenko 2017). In the last 20 years, their rapid northward and southward range expansions in European Russia respectively, have rapidly established both species as widespread and abundant breeding species in many wetlands, with colonies of up to 500-1000 individuals reported in Penza, Moscow and other regions. Despite the preference of Pochard for nesting in tern and gull colonies, very high duckling mortality caused by predation by Caspian Gulls and Herring Gulls has recently been reported from many sites.

Poorly regulated hunting of Pochard in Russia in spring is potentially an additional factor adversely affecting population size, particularly in its core breeding range, in the steppe lakes of the Kalmykia Republic, in Volgograd and Rostov regions. Intensive spring hunting is often a feature of most remaining fishponds, particularly in sites located close to Moscow and other major cities. Spring hunting on wildfowl species was opened in Russia in 1992 and hence since that time has increasingly come to be a new factor affecting survival, settlement and the reproduction success of Pochard in such areas.

\section{Synthesis of trends in Siberia and Far East Russia}

Our knowledge of trends in the changes in distribution and abundance of breeding Pochard is far less well known here than in European Russia. Nevertheless, on the information available, there were marked declines in all areas of Siberia where observers felt able to describe a trend, with the exception of the southern part of Irkutsk Region, where Pochard are considered to be increasing. The breeding range of the Pochard was also reported 
to be expanding in the Russian Far East, particularly in southern part of the region close to the border with China, although the numbers of birds involved are not thought to be very large. There were also suggestions of increases in numbers among the isolated breeding population on Kamchatka Peninsula. It seems possible that the recent Pochard range expansion to the Pacific coastal region could be partly caused by the loss or deterioration of breeding habitats in the steppe and forest-steppe zones of Southern Siberia. This was hypothesized as the cause of the westward expansion of breeding Pochard into eastern and ultimately western Europe, which occurred in the later part of the 1800 s and was considered to be potentially the result of drought in the core breeding areas further east in continental Eurasia (Polyakov 1910; Kalela 1949). The ongoing range expansion and increase in numbers of Pochard in the Russian Far East could potentially constitute a new threat to the critically endangered Baer's Pochard (Aythya baeri) through possible hybridization.

\section{Future perspectives}

It would therefore appear that, for whatever reason, the abundance of Pochard breeding east from European Russia across to Lake Baikal has shown a similar population trajectory to that reported from western Europe. This reflects a range expansion and increase in numbers up until the 1990s, followed by a dramatic decline in abundance (see Fox et al. 2016). Despite these general similarities, we lack adequate information to confirm that the drivers of change in abundance are the same throughout the entire range. It seems highly likely that the loss and changes in management of fishponds in most countries of Eastern Europe and European Russia have contributed to declines there, as have hyper-eutrophication of already nutrient-rich lakes throughout the range. It seems highly likely that more frequent drought has also had a very major impact on wetland and lake extent and quality in the arid and semi-arid systems favoured by the species in the steppe zone of continental Eurasia since 2000 (e.g. Voropay and Ryazanova 2018).

As in western Europe, we lack functional means of monitoring breeding duck species, such as the Pochard, at relatively low densities on the breeding areas. Detectability issues favour monitoring of annual abundance on the wintering quarters, where aggregations are greater and easier to assess, for instance using citizen science networks to generate high quality information at modest cost. Although Russian breeding Pochard winter in western Europe, the Mediterranean, Black and Caspian Seas, as well North Africa, the Middle East, Indian subcontinent and in Japan and China, wintering aggregations in these regions provide the opportunity to follow trends in flyway abundance based on discrete wintering provenance that can track the changing status of the Pochard. Japan and Korea in particular have a proud tradition of annual mid-winter counts that provide a valuable source of data to describe trends for the species in that region. We urge analyses of these data in these wintering regions to confirm the trends we present here, together with a full analysis of metal ring recoveries from Pochard marked in the eastern part of their global range to link breeding and wintering sites to provide some sense of flyway structure across Central and Eastern Eurasia. Such information would provide a rationale for specific site safeguard actions within discrete flyways if these prove to be the case, as well as providing a basis for recommended research to investigate the causes of the decline of this formerly more abundant duck species.

\section{Conclusions}

Based on numerous local assessments, we report widespread declines throughout the eastern breeding range of the Pochard over the last 40 years, which reflect those in the west of the species' range. This exercise showed our present inability to effectively monitor population change in this species on the breeding areas at large spatial scales and urge better surveillance on the winter quarters. We also need better information relating to key factors affecting site-specific Pochard breeding success and abundance, if we are to be able to implement effective actions to restore the species to more favourable conservation status throughout its breeding range.

\section{Acknowledgements}

Authors are grateful to Dmitry Shitikov, Natalia Lebedeva, Andrey Belyachenko, Nikolay Miklin, Vladimir Ryabov and Vasily Dugintsov who have kindly provided their unpublished data for this study.

\section{Authors' contributions}

AM, ADF and SS conceived and designed the research and wrote the manuscript. OS, YL, SK, AC, DV and OO collected and analysed the data on the species concerned available in different regions of Western Palearctic. All authors read and approved the final manuscript.

\section{Funding}

This work was funded by the European Institute for the Management of Wild Birds and their Habitats (France), with support of the French Ministry for Ecological and Inclusive Transition and the French National Hunting Federation.

\section{Availability of data and materials}

Not applicable, our sources are declared throughout the manuscript.

Ethics approval and consent to participate

Not applicable.

\section{Consent for publication}

Not applicable.

\section{Competing interests}

The authors declare that they have no competing interests. 


\begin{abstract}
Author details
${ }^{1}$ A.N. Severtsov Institute of Ecology and Evolution of the Russian Academy of Sciences, Leninskiy Street 33, Moscow 117071, Russia. ${ }^{2}$ Department of Bioscience, Aarhus University, Grenåvej 14, Kalø, 8410 Rønde, Denmark. ${ }^{3}$ Nature Research Centre, Akademijos 2, 08412 Vilnius, Lithuania. ${ }^{4}$ Russian Society for Bird Conservation and Study, Bolshaya Nikitskaya Street 6, 125009 Moscow, Russia. ${ }^{5}$ European Institute for the Management of Wild Birds and Their Habitats, 59 rue Ampère, 75017 Paris, France. ${ }^{6}$ Kuban Scientific-Research Centre, Wildlife of the Caucasus, Teplichnaya Street 58-18, Krasnodar 350087, Russia. ${ }^{7}$ Scientific Practical Centre of National Academy of Sciences of Belarus for Biological Resources, Akademicheskaya Street 27, 220072 Minsk, Belarus.
\end{abstract}

Received: 16 May 2020 Accepted: 8 July 2020

Published online: 14 July 2020

\section{References}

Afton AD, Anderson MG. Declining scaup populations: a retrospective analysis of long-term population and harvest survey data. J Wild life Manage. 2001;65:781-96.

Andreev BN. Birds of Vilyui basin. Yakutsk: Book Press; 1987 (in Russian).

Antonov Al, Parilov MP. Assessment of recent status of protected birds in the east of Amurskaya Oblast. Amurian Zool Mag. 2009;1:270-4 (in Russian)

Azarov VI. Resources of waterfowl in Tobol-Ishim forest-steppe, their conservation and use. PhD Thesis. Moscow: Moscow University; 1991 (in Russian).

Biodiversity Centre of Japan. Survey of waterbirds. Biodiversity Centre of Japan, Tokyo. 2019. https://www.biodic.go.jp/gankamo/gankamo_top.html. Accessed 26 Sep 2019 (in Japanese).

BirdLife International. European red list of birds. Luxembourg: Office for Official Publications of the European Communities; 2015.

Bukreev SA, Chernobay VF. Data on Anseriformes of the Volgograd Sarpa. Casarca. 2011;14:223-39 (in Russian).

Chernichko II, Kostyushin VA. Retrospective review of results of the ornithological monitoring in wetlands: Molochnyi Liman. Results Regional Ornithol Monitoring. 2015;9:68 (in Russian).

Chudnenko DE. Dynamics of bird fauna and populations in peat extractions on a sample of Sakhtysh-Rubskoye area (Ivanovo Region, Russia). In: Population dynamics of birds in terrestrial landscapes. Proceedings of the Russian Scientific Conference ZBS MSU March 17-21 2017. Moscow: KMK Scientific Press; 2017. p. 268-76 (in Russian).

Cramp S, Simmons KEL. Handbook of the birds of Europe, the Middle East and North Africa. The birds of the Western Palearctic, vol. 1. Oxford: University Press; 1977.

Degtyarev AG. Game birds of the Republic of Sakha (Yakutia). Yakutsk: Yakutsk Branch of State Publishing House of SB RAS; 2004 (in Russian).

Degtyarev AG. Waterfowl and waterbirds in the conditions of cryo-arid plain. Novosibirsk: Nauka; 2007 (in Russian).

Elsukov SV. Monitoring of waterfowl of Lake Blagodatnoye in the period of spring and autumn migrations. In: Potichina EV, editor. Results of conservation and study of nature complexes of Sikhote-Alin'. Vladivostok: Primpoligrafcombinat; 2005. p. 173-180 (in Russian).

Elsukov SV. Birds of the North-East Primorie: non-Passeriformes. Vladivostok: Dal'nauka; 2013 (in Russian).

FAO/EBRD. Russian Federation: a review of the fishery sector. New York: UN Food and Agriculture Organisation/European Bank for Reconstruction and Development Cooperation Programme Report N12; 2008.

Fedyushin AV, Dolbik MS. Birds of Belarus. Minsk: Science and technology; 1967 (in Russian).

Fefelov IV, Shinkarenko AV, Podkovyrov VA. Trend of the duck populations in Selenga Delta. Russ Ornithol Mag. 1995;1 (2):45-53 (in Russian).

Fefelov IV, Voronova SG, Povarintsev Al. Numbers and survival of duck broods in the mouth of river Irkut in the last decade. Baikal Zool Mag. 2009;1:94-9 (in Russian).

Fox AD, Caizergues A, Banik MV, Dvorak M, Ellermaa M, Folliot B, et al. Recent changes in the abundance of breeding common pochard Aythya ferina in Europe. Wildfowl. 2016;66:22-40.
Fox AD, Balsby T, Jorgensen $H$, Lauridsen T, Jeppensen E, Sondergaard M, et al. Effects of lake restoration on breeding abundance of globally declining Common Pochard (Aythya ferina). Hydrobiologia. 2019;830:33-44.

Frolov W. Birds of Penza Region and adjacent territories. Vol. 1. Non-passeriformes. Penza: Penza University Press; 2017 (in Russian).

Gerasimov NN, Gerasimov YN. Investigations of migrations of waterfowl and waterbirds in Kamchatka. In: Savelieva AP, Seredkina IV, editors. Ranges, migrations and other movements of wildlife. Materials of the International science and applied conference. Vladivostok: OOO Reja; 2014. p. 52-61 (in Russian).

Gerasimov YN, Gerasimov NN. Birds of Elovka River. In: Artjukhin YB, Gerasimov $\mathrm{YN}$, editors. Biology and conservation of the birds of Kamchatka. No. 8 Moscow: Wildlife Conservation Center Press; 2008. p. 38-64 (in Russian).

Glushchenko YN, Bocharnikov VN, Mrikot KN, Korobov DV. Centuries dynamics of numbers of Anseriformes in Lake Khanka Lowland. In: Bukreev SA, editor. Inventory, monitoring and conservation of IBAs in Russia. No. 5 Moscow: Russian Bird Conservation Union; 2005. p. 19-36 (in Russian).

Glushchenko YN, Shibnev YN, Volkovskaya-Kurdjukova EA. Birds. In: Nazarenko $\mathrm{AA}$, editor. Vertebrates of Zapovednik Khankajskiy and Lake Khanka Lowland. Vladivostok: GPBZ Khankaisky Press; 2006. p. 77-233 (in Russian).

Glushchenko YN, Nechaev VA, Red'kin YA. Birds of Primorski Krai: brief faunistical review. Moscow: KMK Press; 2016 (in Russian).

Glushenkov OV, Isakov GN, Osmelkin EV. Cadastre assessment of condition of gull colonies in Chuvash Republic. Ecol Bull Chuvash Republic. 2007:57:29-44 (in Russian).

Grishanov G, Švažas S. The Neman River delta-internationally important area for migratory wildfowl species. Vilnius: Akstis; 2013 (in Russian).

lovchenko NP. Ecosystems of the nature reserve "Lakes Rakovye": history and present state. Saint-Petersburg: Saint-Petersburg University Press; 2012 (in Russian).

Isakov YA, Ptushenko ES. Order Anseriformes. In: Dementiev GP, Gladkov NA, editors. Birds of the Soviet Union, vol. IV. Moscow: Sovetskaya nauka; 1952. p. 247-635 (in Russian).

Ivanauskas T. Birds of Lithuania Wildfowl, vol. 2. Vilnius: State Publishers of Scientific Literature; 1959 (in Lithuanian).

Kalela O. Changes in geographic ranges in the avifauna of northern and central Europe in relation to recent changes in climate. Bird Banding. 1949:20:77-103.

Kalinina L, Zelenskaya I. Current state and problems of commercial fish-farming development in Russia. SHS Web Conf. 2018;55:01008. https://doi. org/10.1051/shsconf/20185501008.

Kear J. Ducks, Geese and Swans. Bird families of the World. Oxford: University Press; 2005.

Khrabry VM. Game animals of Leningrad Region. Saint Petersburg: Saint Petersburg University Press; 2016 (in Russian).

Klimov SM, Sarychev VS, Melnikov MV, Zemlyanukhin Al. Bird fauna of the Upper Don Basin. Non-passeriformes. Lipetsk: LGPU; 2004 (in Russian).

Komdeur J, Bertelsen J. Manual for aeroplane and ship surveys of waterfowl and seabirds. Slimbridge: International Waterbird and Wetlands Research Bureau Special Publication 19 IWRB; 1992.

Koskimies P, Väisänen RA. Monitoring bird populations: a manual of methods applied in Finland. Helsinki: University of Helsinki, Zoological Museum; 1991.

Krivenko VG, Vinogradov VG. Birds of the water environment and rhythms of climate of the Northern Eurasia. Moscow: Nauka; 2008 (in Russian).

Lobkov EG. Nesting birds of Kamchatka. Vladivostok: Far East Science Centre, USSR Academy of Sciences; 1986 (in Russian).

Lokhman YV, Gozhko AA. Counts of waterfowl, shorebirds and seabirds in the Krasnodar Region in November 2017. Russ J Ornithol. 2017;28:4591-7 (in Russian).

Lysenko V. The fauna of Ukraine Birds. Vol. 5. Anseriformes. Kiev: Naukova Dumka; 1991 (in Russian).

Malchevsky AS, Pukinsky YB. Birds of Leningrad Region and contiguous territories, vol. 1. Leningrad: University Press; 1983 (in Russian).

Melnikov YI, Melnikova NI, Pronkevich W. Materials on the waterfowl fauna in the mouth of river Irkut. Ornithologia. 2003;30:32-7 (in Russian).

Merikallio E. Einwanderungsgeschichte der Vogelfauna des Ayrapaanjarvi-Sees in Suomi Finland Istmus Karelicus. Berlin: Proceedings of the VI International Ornithological Congress, Berlin; 1929. p. 484-93 (in German) 
Miklin NA, Shitikov DA, Babushkin MV. Square 37VDH4, Vologda and Arkhangelsk regions. In: Voltzit OV, Kalyakin MV, editors. The fauna and abundance of European Russia Birds Annual report on the Programme "Birds of Moscow City and the Moscow Region". Moscow: Fiton Century Publications; 2013. p. 351-353 (in Russian).

Mikhantyev Al, Selivanova MA. Population dynamics of several species of ducks in the south of West Siberia (North Kulunda) related to hydrologic, climatic, and meteorological conditions. Casarca. 2016;19:67-80 (in Russian).

Mischenko AL. Value of fishponds of for bird fauna in the conditions of man-made landscape (on an example of Moscow Region). PhD Thesis. Moscow: Moscow State University. 1985 (in Russian).

Mischenko AL. Estimations of numbers and trends for birds of the European part of Russia ("Birds in Europe-II"). Moscow: Russian Bird Conservation Union; 2004.

Mischenko AL. Estimations of numbers and trends for birds of the European Russia ("European Red List of Birds"). Moscow: BirdsRussia; 2017.

Mischenko AL, Sukhanova OV. Fishponds as the main refuges of waterbirds in the Moscow Region. OMPO Newsl. 2006;26:47-50.

Mischenko AL, Sukhanova OV. Results of long-term monitoring of breeding ducks' numbers in Vinoradovo floodplain (Moscow oblast). Casarca. 2016a;19:31-48 (in Russian)

Mischenko AL, Sukhanova OV. Response of wader populations in the Vinogradovo Floodplain (Moscow Region, Russia) to changes in agricultural land use and spring flooding. Wader Study. 2016b;123:136-42.

Moskalev VA. Hunting on waterfowl in Leningrad oblast. Hunting, Peltry Quarry. 1977;56:3-10 (in Russian).

Mundkur T, Langendoen T, Watkins D. The Asian Waterbird Census 2008-2015: Results of coordinated counts in Asia and Australasia. Ede, The Netherlands: Wetlands International; 2017.

Nagy S, Flink S, Langendoen T. Waterbird trends 1988-2012: Results of trend analyses of data from the International Waterbird Census in the AfricanEurasian Flyway. Ede, The Netherlands: Wetlands International; 2014.

Neifeldt IA. Review of the ornithological studies in Karelia. Proc Zool Inst Russ Acad Sci. 1970;47:67-110 (in Russian).

Numerov AD. Birds Aves Natural resources of Voronezh Region Vertebrate Animals Cadaster. Voronezh: Biomik; 1996 (in Russian).

Olney PJS. The food and feeding-habits of the Pochard, Aythya ferina. Biol Conserv. 1968;1:71-6.

Ostrovsky OA, Natykanets W. Monitoring of waterfowl. In: Sushchenya LM, Semenchenko VP, editors. Monitoring of fauna of Belarus basic principles and results. Minsk: Belarus Research Centre of Ecology; 2005. p. 127-35 (in Russian).

Ostrovsky OA, Natykanets WV, Zhuravlev DV. Changes in species composition and abundance of waterbirds of Lake Osveyskoe during the last 30 years. In: Proceedings of the 3rd International Conference on Protected areas of NW Belarus. Vitebsk: Vitebsk University; 2009. p. 66-7 (in Russian).

Petkov N, Hughes B, Gallo-Orsi U. Ferruginous Duck: from research to conservation. Sofia, Bulgaria: Birdlife International-RSPB-TWSG; 2013.

Polivanova NN. Birds of Lake Khanka. Part 1. Vladivostok: DVNC of Academy of Science USSR Press; 1971 (in Russian).

Polyakov Gl. The ornithological fauna of Moscow Province. Materials to knowledge of fauna and flora of Russian Empire. Dept Zoo. 1910;10:1-211 (in Russian).

Ptushenko ES, Inozemtsev AA. Biology and economic value of the birds of Moscow Region and adjacent territories. Moscow: Moscow University Press; 1968 (in Russian)

Ryabitsev VK. Birds of Siberia. A field guide in two volumes, vol. 1. MoscowEkaterinburg: Armchair Scientist; 2014 (in Russian).

Ryazanova NE, Kravchuk MV. Changes of the areas of Sarpinskie Lakes in 2005-2016. In: Akhmetov IG, editor. Materials of the 3rd International Conference on Sciences on the Earth: yesterday, today, tomorrow. Saint Petersburg: Svoyo Isdatelstvo Press; 2017. p. 26-32 (in Russian).

Rusanov GM. Aerial monitoring of mass bird species the Volga avandelta (2006-2010). Ornithol Bull Kazakhstan Cent Asia. 2013;2:146-65 (in Russian)

Sarantseva El. Structure and spatial distribution of bird communities in the valley ecosystems of small rivers in Low Volga Basin. PhD Thesis. Saratov: Saratov State University; 2003 (in Russian).
Sarychev VS, Batishchev DL. Avifauna of the Gryazinsky Fishponds. Bull Rare Plants Animals Lipetsk Region. 2012;5:60-88 (in Russian).

Serebryakov V, Vorobyev E, Gorban I, Davidenko I, Korzyukov A, Lugovoj A, et al. The status and number of certain waterbird species in Ukraine. Kiev: Fitosociocenter Press; 2003.

Shulpin LM. Commercial, hunting and predatory birds of Primorye. Vladivostok: Far Eastern branch of the USSR Academy of Sciences Press; 1936 (in Russian).

Sotnikov VN. Birds of Kirov Region and contiguous territories. Vol.1. Non-passerines. Part 1. Kirov: OOO Triada-S; 1999 (in Russian).

Stepanyan LS. Conspectus of ornithological fauna of Russia and neighbouring territories. Moscow: Nauka; 2003 (in Russian).

Sukhanova OV. Nesting ecology of the Tufted Duck Aythya fuligula and the Pochard Aythya ferina in Central Russia. Gibier Faune Sauvage. 1996;13:709-22.

Syroechkovskiy EE. Field guide of Anseriformes of Russia. Moscow: Zoological Museum of Moscow State University; 2011 (in Russian).

Švažas S, Drobelis E, Balciauskas L, Raudonikis L. Important wetlands in Lithuania. Vilnius: Akstis; 1999.

Švažas S, Kozulin A. Waterbirds of large fishponds of Belarus and Lithuania. Vilnius: Lithuanian Institute of Ecology; 2002.

Takahashi T. On the birds breeding near lake Taraika, S Sakhalin. Tori. 1942;11:370-89.

Tarasov W. Recent condition of recourses of Anseriformes in Tobol-Ishim forest-steppe. In: Popovkina AB, editor. Abstracts of International Conference "Anatidae of North Eurasia: study, protection and wise use". Salekhard: Working group on geese of Northern Eurasia; 2015. p. 89-90 (in Russian).

Tischler F. Die Vögel Ostpreußens und seiner Nachbargebiete. Königsberg und Berlin: Bd.; 1941 1-2 (in German).

Tilba PA, Mnatsekanov RA. Avifauna of Priazovsky Nature Reserve. Acta Sochi National Park. 2014;6:60-120 (in Russian).

Tsyndzhapova ND. Seasonal dynamics of bird population in the wetland complex of city Irkutsk. Bull State Agr Acad Buryatia. 2009;3:138-42 (in Russian).

U.S. Fish and Wildlife Service. Waterfowl population status, 2019. Washington, DC USA: U.S. Department of the Interior; 2019. https://www.fws.gov/ migratorybirds/pdf/surveys-and-data/Population-status/Waterfowl/ WaterfowlPopulationStatusReport19.pdf.

Väänänen VM. Predation risk associated with nesting in gull colonies by two Aythya species: observations and an experimental test. J Avian Biol. 2000;31:31-5.

Väänänen VM, Pöysä H, Runko P. Nest and brood stage association between ducks and small colonial gulls in boreal wetlands. Ornis Fennica. 2016;93:47-544.

Viksne J. The birds of Lake Engure. Riga: Jana seta Press; 1997.

Viksne J, Švažas S, Czajkowski A, Janaus M, Mischenko A, Kozulin A, et al. Atlas of Duck Populations in Eastern Europe. Vilnius: Akstis; 2010.

Voropay NN, Ryazanova AA. Atmospheric droughts in Southern Siberia in the late 20th and early 21 st centuries. IOP Conf Ser Earth Environ Sci. 2018;211:012062.

Vorobiev KA. Birds of Ussurijskiy Kraj. Moscow: USSR Academy of Sciences Press; 1954 (in Russian).

Vorobiev KA. Birds of Yakutia. Moscow: USSR Academy of Sciences Press; 1968 (in Russian).

Voronov LN, Glushenkov OV, Isakov GN, Osmelkin EV, Yakovlev AA, Yakovlev VA. Birds of Chuvashia Non-passeriformes, vol. 1. Cheboksary: Chuvash Press; 2016 (in Russian).

Voronov VG, Voronov GA, Neverova TI, Eremin YP, Voronov GV, Zdorikov AI. Birds of the Lake Nevskoye (Sakhalin Island). Juzhno-Sakhalinsk: SakhKNII; 1983 (in Russian)

Vyazovich V. Ducks of Belarus. Minsk: Vyshejshaya Shkola Press; 1973 (in Russian)

Wang X, Barter M, Cao L, Jinyu L, Fox AD. Serious contractions in wintering range and decline in abundance of Baer's Pochard Aythya baeri. Bird Conserv Int. 2012;22:121-7.

Wetlands International. Flyway trend analyses based on data from the AfricanEurasian Waterbird Census from the period of 1967-2015. Ede, The Netherlands: Wetlands International. 2017. https://www.dropbox.com/ sh/r76f4eyuhzu65co/AADzzQkhySsUDsmwFJUcHs91a?dl=0. Accessed 26 Jun 2020. 
Wetlands International. Waterbird population estimates. 2019. https://wpe. wetlands.org. Accessed 10 Sep 2019.

Zavjalov EV, Shlyakhtin GV, Kapranova TA. Waterfowl and waterbirds of Saratov Region (Gaviformes, Podicipediformes, Pelicaniformes, Ciconiiformes, Phoenicopteriformes, Anseriformes). Berkut: Ukr Ornithol Mag. 1997;6:3-18 (in Russian).

Zavjalov EV, Shlyakhtin GV, Tabachishin VG, Yakushev NN, Khrustov IA. Birds of the northern part of Low Volga Basin. Book 1. Saratov: Saratov University Press; 2005 (in Russian).
Zhukov VS. Birds of Middle Siberia forest-steppe. Novosibirsk: Nauka; 2006 (in Russian).

Zubakin VA, Morozov VV, Kharitonov SP, Leonovich VV, Mischenko AL. The birds of the Moscow-river meadowland near Vinogradovo, Moscow Region. In: Flint VE, Tomkovich PS, editors. Birds of reclaiming territories. Moscow: Moscow University Press; 1998. p. 126-167 (in Russian)
Ready to submit your research? Choose BMC and benefit from:

- fast, convenient online submission

- thorough peer review by experienced researchers in your field

- rapid publication on acceptance

- support for research data, including large and complex data types

- gold Open Access which fosters wider collaboration and increased citations

- maximum visibility for your research: over 100M website views per year

At BMC, research is always in progress.

Learn more biomedcentral.com/submissions 